\title{
Bending the Bed of Procrustes. Gogea Mitu from the Circus Stage to the Boxing Ring
}

\author{
Tímea Barabás \\ University of Bucharest, Romania
}

\begin{abstract}
In the context of the urban landscape of entertainment in Central and Eastern Europe, staged otherness in early $20^{\text {th }}$-century Romania remains a relatively uncharted field. The following paper aims to address this issue by discussing the representation of Gogea Mitu, a circus performer turned boxer, who became famous due to his staggering height in the press. I propose a dislocation of perspective by analyzing the 'deviant' body not in the context of sideshow entertainment, but as it was constructed in mediated sports. By relying on structuralist and poststructuralist theories I address the negotiation of meaning associated with corporeality. The application of Foucauldian discourse analysis as a basis for the interpretation of selected newspaper articles allows for the examination of wider social power relations but also the subject position. As the reading reveals, the 'deviant' body of Gogea Mitu proves to be an ample surface for the refraction of normativity.
\end{abstract}

Keywords: Gogea Mitu, circus, boxing, 'deviant' body, habitus, Romania

"If the monstrous races had not existed, it is likely that people would have created them" (FrIEDMAN 1981:21). There is an ancient call inherent in human nature towards escapism into the far reaches of imagination, rivaled only by an inclination towards the fear of the unknown. These amorphous cravings were addressed in the systematic display of human exhibits, which can be placed in two main categories of constructs: 'exotic savages' and 'freaks'. The carnival provided a safe space for members of the public to indulge their socially repressed desires and curiosities (ATKINSON 2003).

In the following case study, I will follow the construction of the 'staged other' not referring to an exotic individual from a land far away, but to a countryman. Here, 'otherness' is strictly based on a difference of physical nature, as Gogea Mitu was and continues to be up to these days the tallest professional boxer in the world (Fig. 1). Gogu Ștefănescu was born in Mârșani, a village in Romania, on July 14, 1914. He came from a large family, that struggled to make ends meet. Young Gogu soon became a sensation in his own village; by the age of 16 he reached a height of $2.30 \mathrm{~m}$ and the weight of $120 \mathrm{~kg}$ (Berezovschi 1998:50). Stories about the 'giant' reached the ear of a foreign circus owner while he was in the nearby city of Craiova. Mitu soon started a career as a 


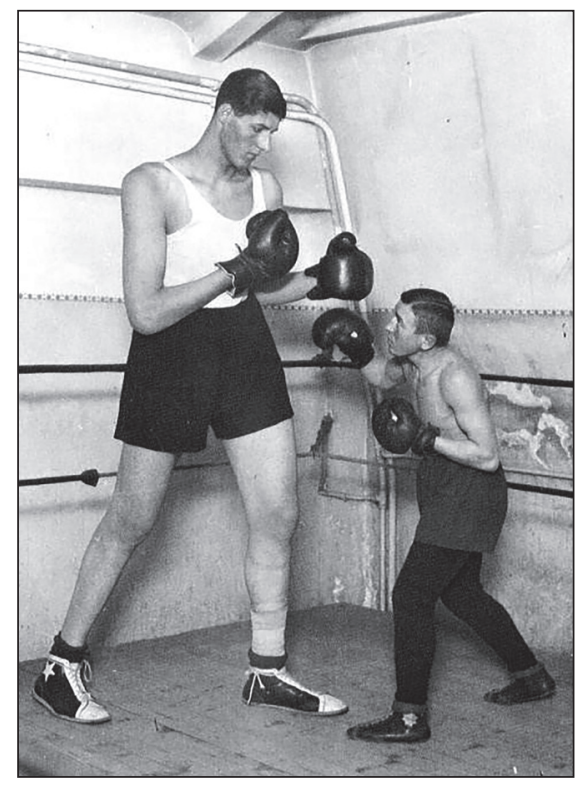

Figure 1. Gogea Mitu training. Bucharest, Romania, December 12, 1934. (MIHAIL 1934:26) performer at circuses and national fairs where he was presented as the tallest man in the world. He famously performed at Târgul Moșilor (Fig. 2), where people paid a fee of 5 lei to see him (BerEZOVSCHI 1998:51).

In 1934, he left the entertainment scene of the circus behind in favor of the world of boxing, inspired by the story of Primero Carnera, ${ }^{1}$ whom he looked up to as a role model (REP. 1934). Gogu finally found a person with similar physical characteristics, whom he could relate to. Carnera's story of success offered him a possible path in life, other than the circus or the fairs. It was in this field that he started making a name for himself. He even featured in the Guinness Book of World Records as the tallest boxer at 7 feet 4 inches $(2.23 \mathrm{~m})$ high and weighing 327 pounds (over $148 \mathrm{~kg}$ ) (MCFARLAN et al. 1990:464). However, his height varies according to sources between 2.20 and $2.44 \mathrm{~m}$, with $2.42 \mathrm{~m}$ appearing most frequently. Under the management of Umberto Lancia, he began training to become a heavyweight professional.

Finding opponents for the 'giant' was not an easy task and consequently Gogea Mitu's first demonstrative match was with his trainer, Lancia (BEREzovschi 1998:51). The event took place at Galați and it caused quite a sensation with the locals and in the newspapers (ReP. 1935e). The professional debut was on June 7, 1935, at Venus Stadium in Bucharest, where he faced his Italian opponent Saverio Grizzo and won by knockout in the first round (ReP. 1935f). The second professional match was with Romanian boxer Dumitru Pavelescu, on Ocober 27, 1935, at Gibb Hall in Bucharest, following the same script, victory by knockout in the first round (C. Mc. 1935). Finally, the Paris match on December 9 of the same year, at the Palais des Sports with Giuseppe Sanga, added the third and final victory to the portfolio of Gogea Mitu (BerEzovschi 1998:52). As no other adversaries could be found, pressured by his manager, Gogea Mitu gave a couple of performances at circuses in France (IUGA - TOMLEt 2001). However, the performance in the ring coupled with backstories of the adversaries led to suspicions on his greatly publicized prowess (REP. 1935f). Still, the fascination of the public lingered on, and negotiations for an American tour were in full force (e.g. REP. 1935c; 1935d). Nevertheless, it all came to a sudden stop, as in 1936 Gogea Mitu passed away of tuberculosis in Bucharest (BerezovsCHI 1998:52; IUGA - TOMLEț 2001:18).

What makes his story particularly interesting is how a 'circus body' transposed to the boxing world. However, this is not a singular case. Recently, researchers turned their attention to such normative infringements and strived to popularize these forgotten

1 Primo Carnera was an Italian professional boxer who was the World Heavyweight Champion from June 29, 1933 to June 14, 1934. He was also famous for his height of $1.97 \mathrm{~m}$ (PAGE 2010). 
biographies (e.g. WALler 2011; MAYes 2003). The subject of displayed bodies in freak shows first gained academic attention with Leslie Fiedler's (1993) Freaks: Myths and Images of the Secret Self, in which she analyzes attractiveness associated with deviance from a Freudian perspective. Another important milestone is marked by Robert Bogdan's (1990) Freak Show: Presenting Human Oddities for Amusement and Profit, where he identifies freakiness as a social construct. Critics (like GERBER 1996) draw attention to the neglect of subject consent in the 'process of enfreakment' (as Hevey 1992 termed it) in these early works, an aspect which would be amply explored in later works (e.g. HEvEY 1992; GaRLAND-Thomson 1996). Nigel Rothfels (1996) emphasizes the importance of the historical and cultural background against the apparent continuity and uniformity of the phenomenon in Western society (see ZITTLAU in the present volume).

The present study aims to contribute to the growing literature targeting the agency of the exposed individuals, in the previously unexplored context of early $20^{\text {th }}$-century Romania. More precisely, I focus on the textual representation of Gogea Mitu's corporeality in mediated sports. Through a structuralist and poststructuralist lens, I analyze the negotiation of meaning in association with a 'deviant' body and conclude that the media directed their 'tall tale' towards his 'deviance' by reinforcing his 'in-between being' (as defined by Grosz 1996²), while Gogea Mitu relied on the commodification of his corporeal self to achieve his own agenda.

\section{AN OUTLINE OF THE LANDSCAPE}

In the following section I plan to take on the difficult task of summarizing the complexities of the international and national socio-political climate at the beginning of the $20^{\text {th }}$ century. Also, I will present a succinct introduction to the evolution of boxing in Romania, in aiming to sketch the context of the research subject, before proceeding to the proper analysis of Mitu's figure and his career.

Following the aftermath of World War I, the international climate of the 1930s was characterized by competing extremist ideologies. As Paul Johnson observes, the fragile world order implemented in the 1920s broke down, "opening an era of international banditry in which the totalitarian states behaved simply in accordance with their military means" (1991:309). Eric Hobsbawm (1995) declared the death of liberalism which opened the ground for communism, Nazism, and fascism to compete for political hegemony. Also, both historians agree that the unprecedented socio-economic and political crises played a crucial role in what was to come. To this predicament, David D. Roberts (2006) also adds the overwhelming sense of possibilities, the seizing of which was an ideological imperative for all the major political players. Meanwhile, the Kingdom of Romania was not exempt from bouts of economic crises and that of political unrest. Based on constitutional monarchy, the kingdom existed from 1881 - marked by the coronation of Carol I - until 1947, when king Michael I abdicated and Romania was proclaimed a socialist republic. During the interwar period, the most influential character in politics

2 'In-between being' is both designating and endangering limits of corporeality and human subjectivity with a direct influence on lived and represented identity. Grosz argues that 'freaks' instigate the very concepts we rely on for a human taxonomy (Grosz 1996). 
was the eldest son of Ferdinand I, Carol II. After his father's death, the crown did not pass unto him, due to scandals of a private nature, but to his son Michael. However, Carol II returned to the country from exile and proclaimed himself king with support from the ruling party of the time, the National Peasants. The 1930s were characterized by a severe destabilization of traditional political parties and a general lean towards the right. The political discourse started gaining extremist and nationalist tendencies, with the far-right gaining more influence through the Iron Guard party. By 1938 the parties were dissolved and a one-party government was established through the National Renaissance Front lead by Carol II, thus installing royal dictatorship (ORNEA 2015; CIUCANU 2009).

Following the outline of the socio-political landscape of the early $20^{\text {th }}$ century, I will now move on to the field of sport. Boxing does not have a very long history in Romania and until the early $20^{\text {th }}$ century, most of the matches and demonstrations took place in the circus or in restaurants, with a few documented exceptions apart from these. The festivities held in 1905, 1906 and 1908 at the "Tirul" sporting society, included a small number of boxing matches, hosting national and international boxers (ALEXE 2002). During the summer of 1909, two foreign boxers (the Irish O'Mara and French Martuin) made quite an impression on the crowd at the Cișmigiu Gardens in Bucharest. By 1910, there was already a boxing tournament organized in several cities in Romania (OCHIALBI - Hent 1969). Another noteworthy event was in 1912, when world champion Jack Johnson made a boxing demonstration at the "Sidoli" Circus of Bucharest, where he defeated Jean Terzieff-Popovici by knockout (ALEXE 2002). However, boxing truly took roots in Romanian society after World War I. Also, the number of training gyms expanded, and the sport started to become institutionalized.

\section{THE BED OF PROCRUSTES}

The relationship between the social agent and society has long been deliberated upon in the field of the social sciences. However, the sociology of the body added a new variable to the equation; namely that of corporeality. Through a social constructionist lens, bodies became flexible constructs under continuous reconstruction, as a result of a negotiation process between society and the self (TURNER 2006). David Le Breton (2002) believes that the body is placed within the general symbolism of society through social representations. On the one hand, these constructs are influenced by a series of factors like social status or a general view of the world; on the other hand, it is through these representations that an individual gains a sense of his or her own body as well as their role in the world. But what happens in the case of 'deviant' bodies, which do not fit into this bed of Procrustes? Without a lack a cultural discourse to guide his/her path, the individual is abandoned to his/her free will.

As a representative of the structuralist perspective, Pierre Bourdieu aspires to reconcile agency and structure by adopting a dichotomic understanding of the relationship formed between the two. The social agent is exposed to different forms of capital throughout his socialization in the field, understood as a set of norms and roles in a social context (BouRDIEU 1986; 2013). There are three main types of capital: economic capital, which is convertible; social capital, constituted from obligations and cultural capital that can become internalized or objectified as products of culture. The body itself is conceptualized as a 


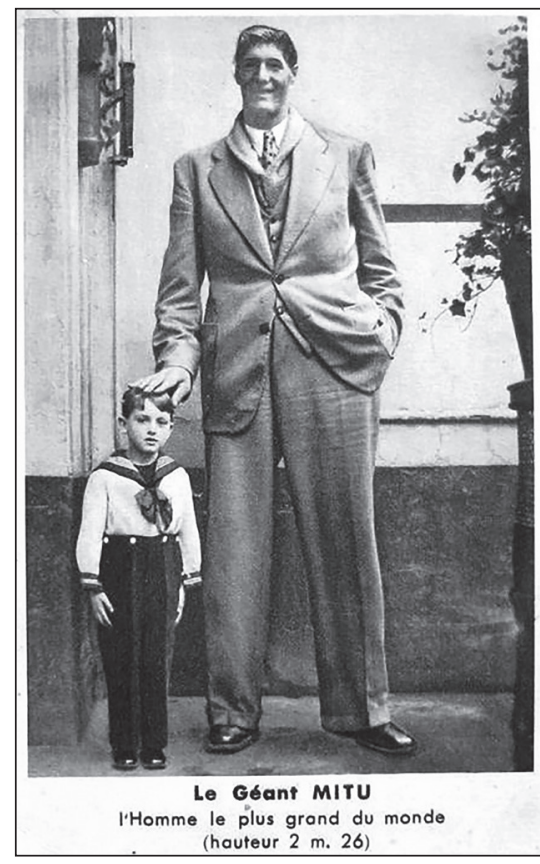

Figure 2. Postcard with Gogea Mitu with French writing, connected to his visit to Paris in 1935. (Retrived from: http://2.bp.blogspot.com/-F6aJFOdeFvg/ UTeHObaq72I/AAAAAAAAAIU/ LmUeqSi-OGc/s1600/Gogea+la+Paris. jpg. Accessed on 05.01.2019) holder of symbolic value, "a possessor of power, status and distinctive symbolic forms integral to the accumulation of various resources" (SHILLING 1993:111). There is a clear link to social status, as corporal management is the principal way of obtaining distinction and prestige (SHILLING 1993).

Through a process of accommodation, the agent eventually internalizes the relationships and expectations that he or she is exposed to, which through time will form Pierre Bourdieu's famous habitus. Claire Edwards and Rob Imrie conclude, "habitus, then, seeks to focus on the corporeal, embodied, experiences of everyday life and to understand systems of interaction between individual social beings and broader social structures in the (re)production of social inequalities" (2003:241). However, statements become incorporated in the very surface and texture of the body, not just in a mental image. In a more simplified reformulation of Pierre Bourdieu's perspective, there is an internalization process of external structures (forming the habitus), but also an exteriorization of social interactions by means of an agent's actions.

Following an outline of theory, in practice, the interrelation between socio-cultural values and 'deviant' bodies remains one of the most underdeveloped areas of research. As Edwards and Imrie formulate it, insufficient attention is turned towards the "dialectical relationship between the individual and society, or where intersubjective and subjective experiences are entwined" (2003:240). Yet there are some noteworthy studies which focus on coping with normativity in the context of social pressure to fit a beautiful body mold. Robert F. Murphy (1990) talks about embattled identities, in describing the conflicting expectations placed upon people with disabilities as well as the concepts of femininity or masculinity. However, 'disabled bodies' can either challenge or conform to cultural beliefs about the beautiful body. In their study on physical disability and masculinity, Thomas Gershick and Adam S. Miller (1995) identify three primary ways of relating to masculinity (reformulation, reliance, rejection). ${ }^{3}$

3 The first, reformulation, implies a distancing from social ideals and their re-interpretation based on personal abilities. An important role in this is played by secure economic resources with the primary role of ensuring independence. Also, an emphasis is placed on career and the success associated with it. The second method, reliance implies accepting the dominant ideals of masculinity. The inability to meet these causes great frustration. Those who adopt this strategy manifest a concern for appearance, strength, independence and control. Finally, the third coping method is rejection, through which the social constructs are recognized and considered as such, and in their place, alternative masculinities are adopted (GERSHICK - MiLLER 1995). 
An interesting conclusion resulting from their research was that the majority of subjects combined several strategies, few only relied on one. Studies such as these highlight the importance of negotiation in attributing meaning to one's own corporeality.

\section{METHODOLOGY}

The main objective of the present article is to analyze the process of negotiation in attributing meaning to a 'deviant' body. I consider the discursive field constructed around the boxing career of Gogea Mitu, as he transitioned from the circus to the sport scene. I have collected data from newspaper articles which cover a time span from August 1934 to June 1936. This time framework is marked by the relative start of Mitu's boxing career and his death. Selected passages are quoted in my translation to English. The text is filtered with the Foucauldian discourse analysis (FDA) to create a multi-layered exploration of the constructs used to build Gogea Mitu's representation in mediated sports. Drawing on the observations of Carla Willig (2008), ${ }^{4}$ this article addresses the role of discourse in the social process of power legitimation. It also considers the position of the subject. Thus, I will consider how the media representation of Gogea Mitu fits into the wider social processes, and how the social agent relates to his own corporeality.

\section{DISCURSIVE CONSTRUCTIONS AND DISCOURSES}

Drawing on press articles covering the boxing career of Gogea Mitu, I identified the 'deviant body' as the discursive object, which was built relying on the following metaphoric constructs: 'Goliath', 'gentle giant' and 'boxing phenomenon'. Mitu's debut in the press was already marked by an association with the first concept (Fig. 3).

\footnotetext{
"The door of the editorial office opened ever so slowly. Just like in police films. Following a foreboding screech, it made way first for a gigantic hand.

The most gigantic hand I have ever seen.

Then, a foot. Also gigantic. And finally - after a couple of seconds of general suspense - an individual appeared.” (REP. 1934:2).
}

The articles that followed did not shift the focus from his height, in fact this differentiating feature was repeatedly outlined through metaphors, exaggerations and comparison to 'normal' sized people. Also, it can be observed how the media brings the reader's

${ }^{4}$ Carla Willig (2008) identifies six stages in the FDA which will serve as the skeletal structure of the analysis: discursive constructions, discourses, action orientation, positionings, practice, subjectivity. The first step is to investigate how the discursive object is constructed (discursive constructions). Next, the differences between the constructs identified in the previous stage are traced and placed within a wider discourse (discourses). Thirdly, the functions and gains associated with ways of constructing the discursive object are explored (action orientation). Then, the analysis is narrowed down to the subject positions (positionings). The following stage (practice) explores the opening and closing of action opportunities by constructions and subject positions. Finally, the last stage (subjectivity) discusses the consequences of the constructs and their impact on subjective experience. 
consciousness of the archetypal figure of the 'giant,' a popular character also in Romanian fairy tales to the foreground. Thus, this idea was part of the collective imaginary. ${ }^{5}$

"Ugh!... in front of me landed the most gigantic Romanian. For a second my hand struggled trapped in his hand, like a small boat hooked by the 'Normandic' steamer" (MENGONI 1935:2).

"Here comes Gogea Mitu. Also for the scale. Still endless and still smiling.

(...)

An official invites him on the scale:

Get on the scale!...

(...)

How much does it hold?...

$150 \mathrm{~kg}$.

Not enough!...

(...)

Let's weigh your shoes!...

For the shoes, the scale of the federation proves to be enough. But do you know how much does his shoes weigh?... Two kg and $800 \mathrm{~g}$. No more, no less" (Fulga 1935:2).

The requirements of 'the giant' referring to a special bed, gloves and menu were continually recirculated in the press, and thus continued to fuel the collective imagination.

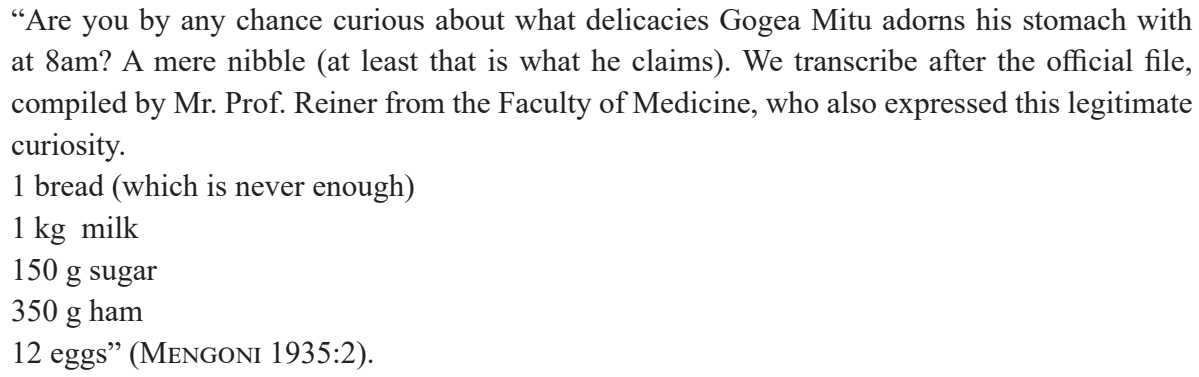

The second dominant construct, that of a 'gentle giant,' comes in somewhat of an opposition. Until now, Gogea Mitu was presented as 'the most gigantic Romanian,' like the 'Normandic steamer' and 'endless,' but there was another side to him. The mediated sports discourse also unveiled another side to this 'Goliath'. This side was marked by physical and psychological traits that emanate fragility and tenderness. Once more, there is an interesting comparison where the expressions of the boxer is likened to the expressions of elephants at play. An image that incorporates in an exemplary way the duality of Gogea Mitu's constitution: he is indeed very tall and powerful, but at the same time harmless and innocent.

5 The giant is a popular character in fairytales, some of the most popular ones are: "Strâmbă-lemne" (Wood-bender), "Sfarmă-piatră" (Stone-crusher). These two also appeared next to Gogea Mitu in an article about giants published in a Romanian illustrated magazine (MiHAIL 1934). 


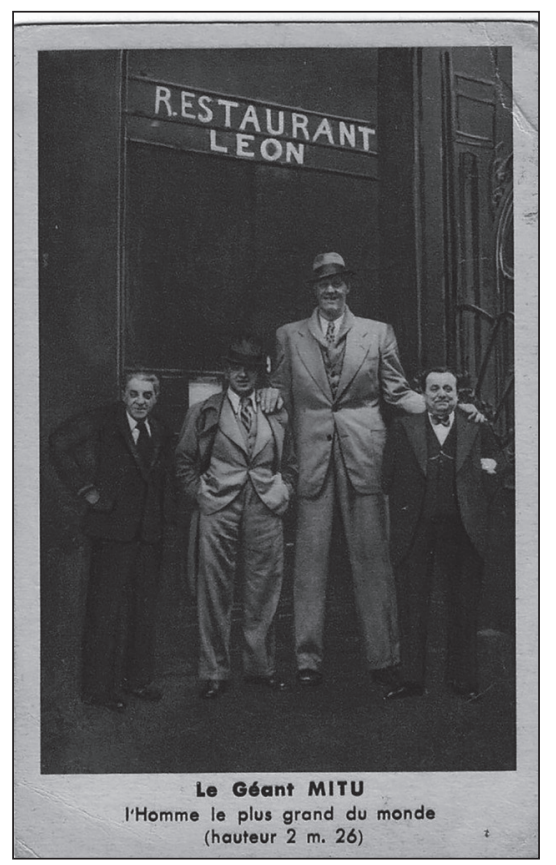

Figure 3. Postcard with Gogea Mitu standing in front of Restaurant Leon. The postcard has French writing and is connected to his 1935 visit to Paris. (Retrieved from: https://www.okazii.ro/34 10-paris-gogea-mitu-born-marsani-nearcraiova-dolj-old-pc-unused-a184624367. Accessed on 05.01.2019)

display is presented within the context of a mainstream entertainment event of sports.

The Romanian equivalent of 'freak' in the context of staged otherness, would be literally be translated as "phenomenon". The double meaning of the word is also sometimes reflected by divergent positions in the press.

First, some examples of Gogea Mitu being portrayed in a very positive light, as a skilled boxer:

"Who said that Gogea Mitu is a phenomenon?... A single phenomenon?...

The 'small' pupil of Lancia is a total phenomenon.

A phenomenon of height. A phenomenon of weight. A phenomenon of sympathy. A phenomenon of boxing" (GEF. 1935:2).

Of the second match: "Neither on this occasion was the first break reached. Gogea Mitu spreads a series of punches, which are soundless, but as heavy as millstones. Touched two, three times, Pavelescu drops to the floor" (C. Mc. 1935:2).
"Gogea talks with a lisp, disarmingly so, adding an air of fragility, naivety and heaviness to this giant creature, just like elephants have when they play" "Long, endlessly long. Heavy, terribly heavy, and Yet, perhaps the most representative of this construct is the following excerpt:

"The descent of Gogea Mitu (from the train) occurred in the middle of a great commotion, a small child offered the giant 'an immense' bouquet of flowers. Gogea Mitu, taking into his arms the child that offered him the flowers and flanked by master Lancia, headed towards the city center, escorted by an ever growing group of curious spectators, which, at some point, blocked the traffic on the main street, making police intervention necessary". (REP. 1935:2)

In the excerpt above, the reporter presents Mitu's arrival to the city of Galati in April of 1935, for his first demonstrative match. He is clearly a crowd favorite; enjoying the attention received, 'deviant bodies' exercise over people. The scene is reminiscent of the circus or freak show context, with the one notable difference that the subject on 
There were also a few articles in which Mitu was presented from a more skeptical perspective. It is through glimpses such as these that a hidden narrative starts to emerge, in which the sporting performance becomes subjugated by the display of a 'deviant body'. This line of narrative will also be picked up and advanced by reporters of our days. ${ }^{6}$

Of the first match: "But this - very beautiful - victory was completely silent.

Because what value does Grizzo have? From the knockout he took from Gogea Mitu, the Italian took a series of other knockouts. Wherever he boxed" (REP. 1935:2).

Of the second match: "Gogea Mitu has won. Obviously. But a victory from six punches does not constitute a sufficient exam for a newcomer. It cannot be affirmed yet, if Lancea's [Lancia - T.B.] student has an inkling of technique. If he knows how to shirk, block, counter, if he indeed possess any of the elementary and indispensable notions of a boxer with pretentions" (REP. 1935f:2).

\section{ACTION ORIENTATION}

The media does not only transmit information, but also directs the gaze of the reader according to its own agenda; in this case, the public eye rests upon the construct of 'Goliath', a 'gentle giant' and a 'boxing phenomenon'. Now I shall analyze some of the functions and implications associated with these characteristics. By constructing the discursive object through contrasting constructs ('Goliath' - a 'gentle giant') the media discourse addresses corporeal volatility, deemed by Nadja Durbach (2010) as the principal characteristic of 'freaks' from the late $19^{\text {th }}$ and the early $20^{\text {th }}$ centuries. The individual is conceptualized as inhabiting two categories at once; thus, also blurring the lines between them. This instability of the body sanctions the social order and becomes politically disruptive, especially with regards to normativity. Furthermore, the deviance becomes a centerpiece surrounded by a crowd characterized by homogeneity. The onlookers become united not only by their common gaze, but also their individual differences are diluted by the contrast to the displayed subject. As Rosemarie Garland-Thomson (1997) sees it, the display of deviance, although not strictly in the context of freak shows, can play a role in defining the cultural self of a nation.

\footnotetext{
${ }^{6}$ A glimpse into the present representation of Gogea Mitu in the media.

"It is said that despite the weak technique and his lack of experience, the impressive stature of Gogea, was actually his strong suite as a boxer" (BoulEanu 2016).

"Therefore, Saverio Grizzo, who lasted 6 rounds with the experienced Motzi Spakow was knocked to the floor by a beginner after only a couple of seconds of fighting, without even delivering a punch. (...) On October 29, 1935, the 'little one' faces Dumitru Pavelescu (...) a brutal boxer at 38, champion at the amateurs in 1926, but without any performance at a professional level, who ended his career with 2 victories and 10 defeats (8 knockout). One year before the match with Gogea, Pavelescu told for Gsp that before certain matches he tends to strengthen himself with some that. Gogea won after the same recipe as in the match with Grizzo - Pavelescu goes to the floor like a good boy in the first round after a couple of seconds" (PESCARU 2013).

While this data will not be considered part of the FDA, I see useful to mention it, as it uncovers and highlights a possible alternative narrative in the mediated sports of the 1930's. I find especially interesting how the secondary narrative of those times moved to the forefront of the press discourse in the $21^{\text {st }}$ century.
} 
As far as considering Gogea Mitu a 'boxing phenomenon', opinions were split. While the majority of articles adopted an optimistic tone and had high hopes for him, there were some who did not declare themselves convinced by his performance. In contemporary media representations (PESCARU 2013; BouleanU 2016), reporters tend to stretch their concern beyond skill, suggesting the possibility of framed matches. Which, if true, shows how a boxing career was built not on performance, but on the display of a 'deviant body' under the pretext of sport. However, one aspect becomes clear. By directing the gaze of the public towards deviance, mediated sports ensured a wider outreach of their discourse, as well as a growing attention manifested towards boxing. His debut demonstrative match at Galați was attended by an estimated number of 2.500 spectators, a considerable record for a city other than the capital (REP.1935e). In fact, as one reporter put it, upon reflecting on Gogea Mitu's possible boxing career, he might have been a welcome change and boost for the Romanian boxing scene that was currently in the rut (G.F. 1935). Therefore, mediated sports centered their discourse more on the sensational aspects of his persona, not unlike a freak show discourse. His boxing career was nothing more than a favorable context for display. I must also mention the influence over the narrative of the sociopolitical climate characterized by great instabilities, since "political statements are frequently situated in the body" (MASON 1992:269). Beyond the political turmoil, during the interwar period in Romania, the far-right emerged as the dominant political discourse, promoting nationalism and a cult of the body (ORNEA 2015). Ideology influences - to a certain degree - all aspects of society, and in matters of corporeality, the field of sports is a particularly important generator of cultural meaning (MASON 1992).

\section{POSITIONINGS AND PRACTICE}

While there is little dialogue or first-hand material from Gogea Mitu unaltered by the media filter, conclusions can still be drawn from his few (and short) published interviews, coupled with his decision-making process and pattern of action. Regarding Gogea Mitu's position on the representation of his body in mediated sports, data shows that he not only accepted the narrative, but also actively contributed to it. As seen in the previous examples, he did not usually shy away from the crowd (Fig. 4). This dominant narrative was disrupted by some contradictory incidents, especially presented in other media sources (e.g. MiHAIL 1934). While most accounts presented Gogea Mitu to be comfortable with crowds, even encouraging them, on occasion, he did feel the need to evade their gaze. The following extract is from an illustrated magazine, not a sports gazette:

\footnotetext{
"A couple of days ago I saw a giant passing under the windows of our editorial agency, he was walking along calmly.

Around fifty people - who all seemed dwarfs, in comparison - were closely following him. In order to escape from the overtly curious crowd, the giant stopped a taxi, but as he was about to get it, he realized that he did not fit. He gave up on the cab and jumped on the no. 6 tram. The people got on as well, and the tram soon became packed" (MiHAIL 1934:25).
}

Furthermore, the opportunities that came and went with regards to his boxing career were closely related to the position adopted by Gogea Mitu. A clear example of this is his 
discussion with Radu Ottulescu, the editor of the boxing section of the Gazeta Sporturilor (the Sport Gazette), where they negotiate the management of his boxing career:

“ $40 \%$ of earnings of a probable 'Carnera,' constitute an interesting perspective.

- Not bad!.. thought Mr. Ottulescu.

But he immediately remembered the even more interesting perspective of financing a year's worth of food and beverage of a man weighing 150 kilograms and he suddenly knocked out his enthusiasm.

- I mean, it's not really that good!

And because, except from having 'Carnera' in pension for one year, he also had to order him a special bed - fitting his length - he quit definitely...” (REP. 1935e:2).

At the end, Mr. Ottulescu invited him to train with him, but to eat on his own expense. He proposed a foreign manager for Gogea Mitu, under the pretext that his height will be an impediment in finding opponents from Romania. In this case, the interest fell on the professional attributes and most of all, on the possibility of becoming a boxing champion; these were, however, the implications (mainly financial) associated to a 'deviant body' that closed this opportunity and consequently opened another. His manager to be, Umberto Lancia, possessed qualities of showmanship and fueled the media discourse with sensational material regarding his 'pensioner'. ' The ascension of Gogea Mitu actually became an international affair. After a demonstrative two round match in Paris on December 9, 1935, he was preparing to "conquer" the boxing world in America (e.g. REP. 1935c; 1935d), a dream that did not come into existence, due to his death. Finally, an accomplishment, which did materialize due to his switch of entertainment scenes, is that he became and still is the tallest boxer in the Guinness Book of World Records (MCFARLAN et al. 1989:464).

\section{SUBJECTIVITY}

To begin with, I shall take a look at what drove Gogea Mitu to leave the circus stage behind for the boxing ring, in the hopes of outlining his subjective discourse. As he admitted in an interview, his main motivation was financial profit:

"- And how did you come up with the idea of boxing?

- Reading how much foreign boxers earn.

- Only this?

- And after a fight - added the new Carnera - during which I knocked out five adversaries" (REP. 1935e:2).

Another important factor was Primo Carnera - even though they never met. His story exercised a great influence on the decision-making process of Gogea Mitu. After spending his entire life as a misfit, Gogea finally found someone similar that he could

\footnotetext{
7 The term of 'endearment' was used by the media at the time, most especially with regards to boxers.
} 


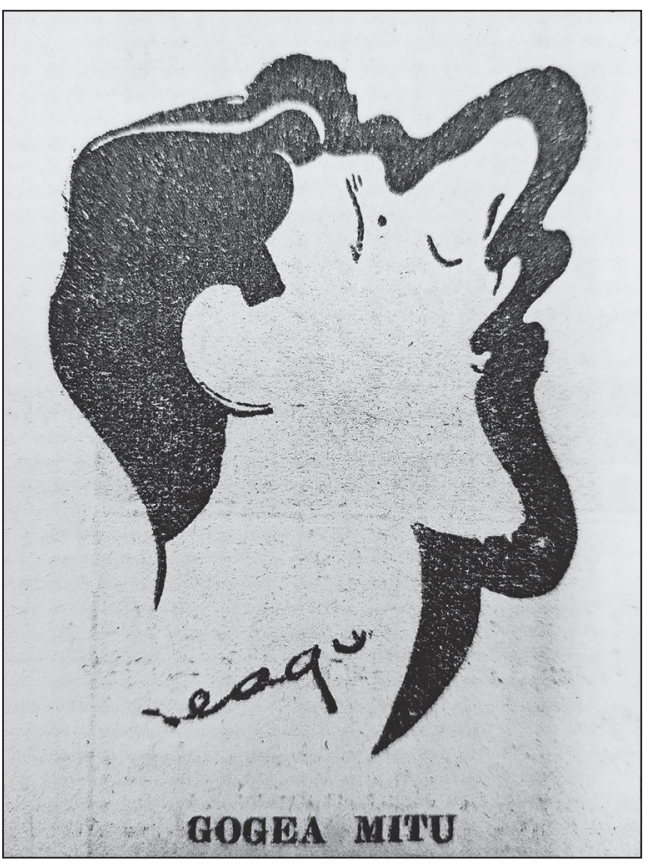

Figure 4. A popular caricature of Gogea Mitu found in numerous articles of the Gazeta Sporturilor [Sport Gazette], e.g. "Gogea Mitu și Lancia vor face un turneu de exhibiții prin Europa" [Gogea Mitu and Lancia will embark on a European tour]. Gazeta Sporturilor, (July 5, 1935) Bucharest, 12(1740):2

relate; something to aspire to beyond the circus stage. In the previously mentioned discussion with Mr. Ottulescu, he even requested to be represented by the first manager of his idol, Leon Seé, although this did not lead to an actual collaboration (G.F. 1935). This is a perfect illustration of the importance of a cultural representation of corporeality in forming one's identity and guiding life choices. David Le Breton (2002) asserts that in the absence of such a landmark, the individual is abandoned and left in a vulnerable state in the face of existential issues like sickness, loneliness or death. In order to escape this sense of anxiety and loneliness, individuals can look for alternative narratives - Gogea Mitu seems to have found one.

In line with Pierre Bourdieu's (1986, 2013) perspective, his body can be viewed as being invested with symbolic value, which, in turn, can be curated by the agent in accordance with his or her own agenda. Gogea Mitu embraced his uniqueness and through the commodification of his corporal self, ensured a larger public outreach. Even after switching the entertainment scenes, the practice of body display maintained as a sensationalist aspect, which was mainly fueled by the media. He dazzled the curious public with tricks relying on his staggering height, all the while actively seeking and managing their gaze. However, there is no reason to believe that he did not take his training seriously, in order to become a truly good boxer.

\section{CONCLUSION}

In the present paper I conducted a case study analysis of a circus performer turned boxer, as well as the repercussions of this transition in early $20^{\text {th }}$-century Romania. Gogea Mitu was a popular entertainer of the times. Now he is but one of the emblematic figures lost in the collective memory of the nation (Fig. 5). I focused on how the association of meaning was negotiated around Mitu's corporeality between mediated sports and the subject. By coupling the construct with opposing features like innocence and playfulness, the press highlighted the hallmark of a 'freak' with corporeal volatility. Against the backdrop of an enforced deviance, these markers of difference exaggerated through figures of speech - mainly metaphors and similes - became emblematic of a staged otherness and were thus, consequently distanced from the homogenous group of onlookers (to which the 
newspaper reader of the time also belonged). However, Gogea Mitu also relied on molding the presentation of his corporeal self in accordance with social expectations in the hopes of fulfilling his personal agenda, to obtain the professional success and popularity that would ensure financial well-being. Additionally, as noted above, the possibility - timidly outlined in the press of the times, but more so in contemporary articles (PESCARU 2013; BOULEANU 2016) - that the matches might have been staged. This raises the question of how 'deviant bodies' are displayed differently, under different contexts.

Finally, I hope to contribute to the ever-growing literature dedicated to the agency of the subject in relation to the 'enfreakment' process in a socio-temporal context that flew under the academic radar, thus expanding the current understanding of the phenomenon and its evolution. In following the representation of a former circus entertainer in the professional boxing world, I draw attention to the fact that the aforementioned process is not exclusively related to the realm of freak shows, sideshows or circus entertainment scenes. Due to the exploratory case study like nature of my research, it would be a stretch to draw certainties or generalizations regarding wider social processes. My aim is to draw attention to certain neglected areas of research and invite further reflection on possible implications signaled by the 'tall tale' of Gogea Mitu.

\section{REFERENCES CITED}

Alexe, Nicu

2002 Enciclopedia Educației Fizice și Sportului din România [Encyclopedia of Physical Education and Sport] vol. I. București: Aramis.

ATKINSON, Michael

2003 Tattooed: the Sociogenesis of a Body Art. Toronto: University of Toronto.

BerEzovschI, Valentin

1998 Olteni in ring [Oltenians in the Ring]. Craiova: Agora.

BoGDAN, Robert

1990 Freak Show: Presenting Human Oddities for Amusement and Profit. Chicago: University of Chicago Press.

BOULEANU, Elisabeth

2016 Povestea lui Goliat de România: celebrul boxer Gogea Mitu a avut 2,42 metri [The Story of Romania's Goliath: the Famous Gogea Mitu Had 2,42 Meters]. Adevărul (August 14 issue) https://adevarul.ro/locale/alexandria/ povestea-goliat-romania-celebrul-boxer-gogea-mitu-avut-242-metri-1_57aec 8f65ab6550cb8b8048e/index.html (accessed January 15, 2019).

BOURDIEU, Pierre

1986 The Forms of Capital. In Richardson, John (ed.) Handbook of Theory and Research for the Sociology of Education, 241-258. Westport, CT: Greenwood.

2013 Outline of a Theory of Practice. Cambridge: Cambridge University Press.

C. Mc.

1935 Gogea Mitu învingător! [Gogea Mitu, a Winner!]. Gazeta Sporturilor (October 29 issue) [Bucharest] 13(1856):1-2. 
Ciucanu, Corneliu

2009 Dreapta românească interbelică. Politică și ideologie [The Interwar Romanian Right. Politivs and Ideology]. Iași: Tipo Moldova.

DurbaCH, Nadja

2010 The Spectacle of Deformity. Freak Shows and Modern British Culture. Berkeley: University of California Press.

EDWARDS, Claire - IMRIE, Rob

2003 Disability and Bodies as Bearers of Value. Sociology 37(2):239-256.

FIEDLER, Leslie A.

1993 Freaks: Myths and Images of the Secret Self. Anchor: New York.

FrIEDMAN, John Block

1981 The Monstrous Races in Medieval Art and Thought. Cambridge: Mass London: Harvard University Press.

FULGA, George

1935 Cântarul lui Gogea Mitu... [Gogea Mitu's Scale]. Gazeta Sporturilor (October 31 issue) [Bucharest] 13(1858):1-2.

G.F.

1935 Va deveni Gogea Mitu un bun boxeur? [Will Gogea Mitu Become a Good Boxer?]. Gazeta Sporturilor (April 18 issue) [Bucharest] 13(1674):1-2.

GARLAND-THOMSON, Rosemarie (ed.)

1996 Freakery: Cultural Spectacles of the Extraordinary Body. New York: New York University Press.

1997 Extraordinary Bodies: Figuring Physical Disability in American Culture and Literature. New York: Columbia University Press.

GeF.

1935 Când se zguduie dușumeaua la C.F.R. [When the Floor Shakes at the C.F.R.]. Gazeta Sporturilor (October 24 issue) [Bucharest] 13(1850):2.

Gerber, David A.

1996 "The 'Careers' of People Exhibited in Freak Shows: The Problem of Volition and Valorization". In GARLAND-Thomson, Rosemarie (ed.) Freakery: Cultural Spectacles of the Extraordinary Body, 38-54. New York: New York University Press.

Grosz, Elizabeth

1996 Intolerable Ambiguity: Freaks as/at the Limit. In Garland-Thomson, Rosemarie (ed.) Freakery: Cultural Spectacles of the Extraordinary Body, 55-66. New York: New York University Press.

Hevey, David

1992 The Creatures that Time Forgot: Photography and Disability Imagery. London: Routledge.

Hobsbawm, Eric

1995 Age of Extremes: The Short Twentieth Century 1914-1991. London: Abacus. IUGA, Coriolan - TOMULeT, Virgil

2001 Stelele boxului românesc și internațional [The Stars of Romanian and International Boxing]. Cluj-Napoca: Cartimpex. 
Johnson, Paul

2010 Modern Times: The World from the Twenties to the Nineties (Revised Edition). New York: HaperCollins.

LE Breton, David

2002 Antropologia corpului și modernitatea [Anthropology of the Body and Modernity]. Timişoara: Amarcord.

MASON, Gay

1992 Looking into Masculinity: Sport, Media, and the Construction of the Male Body Beautiful. Social Alternatives 11(1):27-32.

MAYES, Stanley

2003 The Great Belzoni, The Circus Strongman who Discovered Egypt's Ancient Treasures. London: Tauris Parke Paperbacks.

Mcfarlan, Donald - Boeh, David A. - Mcwirter, Norris Deward

1989/1990 Guinness Book of World Records 1990 (28th ed.). New York: Sterling Publishing Co.

Mengoni, S,.

1935 Gogea Mitu se antrenează [Gogea Mitu is Training]. Gazeta Sporturilor [Bucharest]. http://vanatoruldelegende.blogspot.com/2013/03/gogea-mitucolosul-de-lut.html Accessed on 05.01.2019.

Minail, Alex F

1934 Uriași și Pitici [Giants and Dwarfs]. Realitatea Ilustrată (December 12 issue) [Bucharest] 8(412):25-29.

MurPhy, Robert F.

1990 The Body Silent. New York: Norton.

OCHIAlbi, Paul - Henț, Petre

1969 Pagini din boxul românesc [Pages in Romanian Boxing]. Bucharest: Editura Consiliul Național pentru Educație Fizică și Sport.

ORNEA, Zigu

2015 Anii treizeci. Extrema dreaptă românească [The Thirties. The Romanian FarRight]. Bucharest: Cartea Românească.

Page, Joseph S.

2010 Primo Carnera: the life and career of the heavyweight boxing champion. Jefferson. N.C.: McFarland.

Pescaru, Octavian

2013 Gogea Mitu, Colosul de Lut [Gogea Mitu, the Clay Giant] (March 17 issue). REP. http://vanatoruldelegende.blogspot.com/ (accessed January 9, 2019).

1934 Un super-Carnera roman: Gogu Ştefănescu. 2,20 cm şi 140 kg [A Romanian Super Carnera: Gogu Ștefănescu. 2,20 cm and 140 kg]. Gazeta Sporturilor [Bucharest] XII-1315):1-2.

1935a Vineri 7 Iunie, Gogea Mitu debutează pe ringul bucureștean [Friday, June 7. Gogea Mitu debuts in Bucharest]. Gazeta Sporturilor (May 30 issue) [Bucharest]. 13(1704):1-2.

1935b Mâine seară la Gib: prima reuniune de toamnă [Tomorrow Night at Gib: the First Autumn Reunion]. Gazeta Sporturilor (October 26 issue) [Bucharest] 13(1853):2. 
1935c Americanii se interesează din nou de Gogea Mitu [The Americans Are Interested in Gogea Mitu]. Gazeta Sporturilor (September 17 issue) [Bucharest] 13(1814):2.

1935d Contractele pentru Gogea Mitu sânt pe drum [The Contracts for Gogea Mitu Are on Their Way]. Gazeta Sporturilor (September 24 issue) [Bucharest] 13(1821):2.

1935e "Debutul lui Gogea Mitu la Galați”"/“Gogea Mitu’s Debute at Galați”. Gazeta Sporturilor (April 12 issue) [Bucharest], 13(1656):2.

$1935 \mathrm{f}$ Aseară la Venus: reuniunea knock-outurilor [Last Night at Venus: Reunion of the Knockouts]. Gazeta Sporturilor [Sport Gazette] (June 7 issue) [Bucharest] 13(1712):1-2.

RoBERTS, David D.

2006 The Totalitarian Experiment in Twentieth-Century Europe: Understanding the Poverty of Great Politics. New York: Routledge.

RoTHFELS, Nigel

1996 Aztecs, Aborigines, and Ape-People: Science and Freaks in Germany, 18501900. In Garland-Thomson, Rosemarie (ed.) Freakery: Cultural Spectacles of the Extraordinary Body, 158-172. New York: New York University Press.

TURNER, Bryan S.

2006 The Sociology of the Body. In Bryant, Clifton D. - Peck, Dennis L. (eds.) 21st Century Sociology: A Reference Handbook, 90-97. New York: Sage Publications.

SHILLING, Chris

1993 The Body and Social Theory. London: Sage.

WALLER, David

2011 The Perfect Man. The Muscular Life and Times of Eugen Sandow, Victorian Strongman. Brighton: Victorian Secrets Limited.

WiLLIG, Carla

2008 Introducing Qualitative Research in Psychology (2nd ed.). Berkshire: Open University Press.

Tímea Barabás is a Ph.D. candidate in the Department of Sociology at the University of Bucharest. Her thesis takes on the body as a medium in a total institution, focusing on tattooed women prisoners in Romania. This comes as an extension of her ongoing academic interest in the human condition under oppressive regimes. For her Master's Degree in Applied Psychology in National Security she presented a dissertation entitled The Psychological Profile of a Torturer - Eugen Turcanu, offering an analysis of the motivational drive behind the main torturer in the infamous Pitești Experiment conducted during the communist regime. She has been exploring the human condition and its numerous incarnations during times of oppression. E-mail: time_barabas@ yahoo.com 